\title{
Decreased DNA Synthesis by Cultured Osteoblastic Cells in Eugonadal Osteoporotic Men with Defective Bone Formation
}

Pierre J. Marie, Marie Christine de Vernejoul, Danielle Connes, and Monique Hott

Unité 18 Institut National de la Santé et de la Recherche Médicale, Hôpital Lariboisière, 75010 Paris, France

\begin{abstract}
To determine the osteoblastic dysfunction that may be involved in the pathophysiology of osteoporosis in men we have compared histomorphometric indices of bone formation with in vitro characteristics of osteoblastic cells isolated from the trabecular bone surface in 23 untreated men with eugonadal osteoporosis. In most patients $(n=14)$, trabecular bone loss resulted from decreased bone formation evidenced by a lower than normal osteoblast surface, double tetracycline labeled surface, bone formation rate, and mean wall thickness. In these patients, DNA synthesis by cultured osteoblastic cells was altered. The peak of $\left[{ }^{3} \mathrm{H}\right]$ thymidine incorporation into DNA, the maximal DNA synthesis, and the area under the curve of cell proliferation were lower than the values in normal bone cells from age-matched controls. Parameters of bone cell growth were decreased in correlation with the extent of actively bone forming surfaces. By contrast, in patients $(n=9)$ with normal histomorphometric indices of bone formation, bone cell proliferation in vitro was not different from normal. Parameters of osteoblastic differentiation in vitro such as osteocalcin production and alkaline phosphatase activity were normal in the two groups of patients. This study shows that the trabecular bone loss resulting from defective bone formation in eugonadal osteoporotic men is associated with a lower than normal proliferative capacity of osteoblastic cells lining the trabecular bone surface. (J. Clin. Invest. 1991.88:1167-1172.) Key words: osteocalcin • cell proliferation $\bullet$ osteoblasts $\bullet$ cell cultures $\bullet$ bone histomorphometry
\end{abstract}

\section{Introduction}

Vertebral fractures and osteoporosis are clinical entities observed in middle-aged men although their incidence is less frequent than in aged men. The etiology of the trabecular bone loss and osteopenia which results in vertebral crush fractures in young and middle-aged patients is poorly understood. An agerelated bone loss has been described in normal men $(1,2)$ but the trabecular bone loss occurring with age is a slow process as it results mainly from thinning of trabeculae $(3,4)$ rather than from perforation of trabecular plates. Several factors may be contributing to the trabecular bone loss in eugonadal men with

Address reprint requests to P. J. Marie, Ph.D., Institut National de la Santé et de la Recherche Médicale, Unité 18, 6 rue Guy Patin, 75010 Paris, France.

Received for publication 7 August 1990 and in revised form 22 February 1991.

J. Clin. Invest.

(c) The American Society for Clinical Investigation, Inc. 0021-9738/91/10/1167/06 \$2.00

Volume 88, October 1991, 1167-1172 osteoporosis. Excess ethanol intake may cause osteoporosis (57) by directly inhibiting osteoblast function and bone formation (8-11). Tobacco use has also been reported to have deleterious effects on bone mass $(5,12,13)$ and osteoblast activity $(8)$. Although studies on trabecular bone formation using dynamic bone histomorphometry have indicated that the recruitment and activity of osteoblasts may be altered in men with idiopathic osteoporosis $(8,11,14)$, the cellular osteoblastic dysfunction responsible for the defective bone formation in these patients remains unknown.

We have thus attempted to determine whether the reduced bone formation in eugonadal men with idiopathic osteoporosis results from an impaired proliferative capacity of osteoblastic cells or from defective bone cell differentiation. This can be determined by comparing in vivo bone forming features with in vitro osteoblastic characteristics $(15,16)$. We have therefore evaluated biochemical and histomorphometric parameters of bone formation and determined in vitro characteristics of osteoblastic cells isolated from a group of eugonadal men with osteoporosis. We found that the defective bone formation occurring in a subgroup of men with osteoporosis is associated with an impaired proliferative capacity of osteoblastic cells in vitro.

\section{Methods}

\section{Patients}

We studied 23 untreated men (mean age: $53.9 \pm 13.4$ (SD) yr, range: 21-77 yr) referred to our center for screening of osteoporosis. $16 \mathrm{pa}-$ tients had osteoporosis as defined by one or more vertebral crush fractures. Seven patients had osteopenia defined as reduced bone mineral content as evaluated by dual photon absorptiometry $(<1$ SD below age-adjusted mean bone density values, which is considered to be the fracture threshold) (17). Two patients (aged 75 and $77 \mathrm{yr}$ ) had involutional osteoporosis. 21 patients (mean age: $51.7 \pm 12.0 \mathrm{yr}$, range: $21-68$ yr) were classified as having idiopathic eugonadal osteoporosis as none had evidence of endocrine or neoplastic disease (18). None had reduced serum testosterone levels, abnormal serum parathyroid hormone (fragment 1-84) levels, or low 1,25 dihydroxyvitamin $\mathrm{D}\left(1,25(\mathrm{OH})_{2} \mathrm{D}\right)^{1}$ levels. 13 patients $(56.5 \%)$ were mild drinkers or smokers $(n=3)$ or both $(n$ $=10$ ) as they stated that they had been drinking at least $100 \mathrm{~g}$ alcohol per day for several years or were smoking more than 15 packs-yr (packs/day $\times$ number of years smoking) or both. Among the remaining eight patients with idiopathic osteoporosis who were neither smokers nor drinkers, three had mild hypercalciuria ( $>9 \mathrm{mmol} /$ liter), two had a slight hypophosphatemia ( $<27 \mathrm{mg} /$ liter), and one had a familial history of fracture. A bone biopsy was performed in each patient after informed consent was obtained. Control histomorphometric parameters were obtained from previously studied eight normal age-matched men (mean age: $43.7 \pm 16.9 \mathrm{yr}$; range: $20-70 \mathrm{yr}$ ) (8).

1. Abbreviations used in this paper: BFR, bone formation rate; DLS, double labeled surface; MWT, mean wall thickness; $1,25(\mathrm{OH})_{2} \mathrm{D}, 1,25$ dihydroxyvitamin $\mathbf{D}$. 


\section{Serum biochemistry}

Serum osteocalcin was determined in duplicate by RIA using kits obtained from ORIS (Centre d'Energie Atomique, Gif sur Yvette, France) using an antibody raised against bovine osteocalcin. The maximum inter- and intraassay coefficients of variation for the range of concentrations evaluated were $6.8 \%$ and $6.5 \%$, respectively. The lower detection limit of the assay was $0.35 \mu \mathrm{g} / \mathrm{liter}$.

\section{Bone histomorphometry}

Undecalcified transiliac bone biopsy specimens were obtained after double tetracycline labeling (labeling sequence: $2 \mathrm{~d}$ on, $10 \mathrm{~d}$ off, and $2 \mathrm{~d}$ on tetracycline). They were performed with an 8-mm inner diameter trephine in the antero-superior iliac crest. The biopsy was placed in sterile PBS and sectioned longitudinally to separate the biopsy in two symmetric half-cores $(15,16)$. Half of the biopsy was processed for bone histomorphometry; the other half was used for bone cell isolation procedures. The half-core for bone morphometry was fixed in formolmethanol and embedded in methyl-methacrylate. Sections $(5 \mu \mathrm{m}$ thick) were stained with toluidine blue, and $10-\mu \mathrm{m}$ thick sections were kept unstained for examination under fluorescent illumination. Parameters of bone formation were determined by conventional histomorphometric methods $(8,15,16)$ using an integrator (Zeiss II; Carl Zeiss, Inc., Thornwood, NY) and a semiautomatic image analyzer (Leitz ASM, Rueil, France). The following parameters were measured on the endosteal surface of the trabecular bone: trabecular bone volume, expressed as a percentage of endosteal bone tissue; osteoblast surface (percentage of trabecular bone surface covered with plump osteoblasts), and mean wall thickness (MWT; micrometers), that is the mean apparent thickness of complete bone packets, obtained by measuring the width of a complete packet perpendicular to the marrow surface (19). The tetracycline-labeled surfaces were analyzed to determine the fractional trabecular surface covered with two labels (double labeled surface [DLS]; percentage), which represents the fraction of trabecular surface actively involved in bone formation at the time of biopsy, and the mineral apposition rate (micrometers per day), which represents the functional activity of osteoblasts. The total labeled surface was determined as the sum of DLS and half of the single labeled surfaces. The tissue level bone formation rate (BFR) was obtained by multiplying the mineral apposition rate by total labeled surface (20). We also determined the osteoclastic surface (percentage of trabecular bone surface covered by osteoclasts) and the number of osteoclasts per $\mathrm{mm}^{2}$ of bone tissue.

\section{Bone cell cultures}

Cell isolation procedure. Osteoblastic cells were isolated from the trabecular bone surfaces of half of the biopsy core as previously described $(15,16,21)$. The soft connective tissue and the periosteal and corticoendosteal bone were removed and the trabecular bone was minced in small $\left(1-\mathrm{mm}^{3}\right)$ fragments. The adherent marrow cells were removed by several washes in PBS. The bone chips were then placed on an 80- $\mu \mathrm{m}$ pore size nylon mesh maintained between two rings in culture dishes to separate adherent bone cells from smaller marrow cells $(21,22)$. The bone explants were cultured in DMEM supplemented with glutamine (292 mg/liter), antibiotics ( $100 \mathrm{U} / \mathrm{ml}$ penicillin and $100 \mu \mathrm{g} / \mathrm{ml}$ streptomycin), and $10 \% \mathrm{FCS}$, and were incubated at $37^{\circ} \mathrm{C}$ in a humidified $(95 \%)$ atmosphere with $5 \% \mathrm{CO}_{2}$. Cell outgrowth from the trabecular bone surfaces was apparent after 4-7 d. When confluency was obtained on the nylon mesh, the adherent cells were dissociated with $0.5 \mathrm{~g} /$ liter trypsin (Sigma Chemical Co., St. Louis, MO) in calcium- and magnesium-free PBS and were plated at the density required for the experimental procedures. Since we found previously that the phenotypic expression of human bone cells decreases as early as after three passages (21), only primary cell cultures were used for analysis of DNA synthesis. For other experiments cells were used after only one cell passage. The osteoblastic cells isolated from the trabecular bone surface using this procedure consisted of $>50 \%$ alkaline phosphatase-positive, morphologically homogeneous cells which predominantly synthesize type I collagen, show alkaline phosphatase activity, and respond to human
PTH (1-34) (21). The cells also synthesize osteocalcin, a specific osteoblast protein, and its production is increased by $1,25(\mathrm{OH})_{2} \mathrm{D}(21)$.

Alkaline phosphatase activity. Bone cell alkaline phosphatase activity was studied in the absence or presence of $1,25(\mathrm{OH})_{2} \mathrm{D}$. Cells cultured at confluence were incubated in DMEM supplemented with $10^{-8}$ $\mathrm{mol} /$ liter vitamin $\mathrm{K}, 50 \mathrm{mg} / \mathrm{liter}$ ascorbic acid, and $10 \mathrm{~g} / \mathrm{liter} \mathrm{BSA}$ in the presence of $10 \mathrm{nmol} /$ liter $1,25(\mathrm{OH})_{2} \mathrm{D}$ or solvent (ethanol). After $48 \mathrm{~h}$, the cells were washed in cold PBS, the cell layer was scraped into $2 \mathrm{ml}$ cold distilled water and sonicated, and the cell lysate was centrifuged. Alkaline phosphatase activity was determined in the supernatant using phenylphosphate as substrate. The protein content of the cell lysates was measured by the method of Lowry et al. (23). The enzymatic activity was expressed as nanomoles of $p$-nitrophenol released per minute per milligram protein.

Osteocalcin production. Osteocalcin production was determined in the presence or absence of $10 \mathrm{nmol} /$ liter $1,25(\mathrm{OH})_{2} \mathrm{D}$. Cells at first passage were grown to confluence and incubated for $48 \mathrm{~h}$, as described above, for the determination of alkaline phosphatase activity. After incubation, the medium was removed and the cellular protein content was determined. The medium osteocalcin concentrations were measured by RIA, as described above.

DNA synthesis. The proliferative capacity of the bone cells was measured by determining the incorporation of $\left[{ }^{3} \mathrm{H}\right]$ thymidine into DNA $(15,16,21)$. All bone cell populations from control and osteoporotic patients were plated at an identical initial density of 10,000 cells/ $\mathrm{cm}^{2}$ in 24-well plates and were cultured in DMEM supplemented with $10 \%$ FCS for $24 \mathrm{~h}$ to allow attachment and recovery from trypsinization. At that time (day 0), the medium was removed and replaced with DMEM with $10 \% \mathrm{FCS}$, and $2 \mu \mathrm{Ci} 6-\left[{ }^{3} \mathrm{H}\right]$ thymidine in $50 \mu \mathrm{l}$ was added. The bone cells were labeled with $\left[{ }^{3} \mathrm{H}\right]$ thymidine on days $0,2,6,8$, and 13 , and $\left[{ }^{3} \mathrm{H}\right]$ thymidine incorporation into bone cells was determined $24 \mathrm{~h}$ later on days $1,3,7,9$, and $14(15,16,21)$. After $24 \mathrm{~h}$ the medium was removed and the cell layer was collected by trypsinization. DNA was precipitated by trichloroacetic acid and the trichloroacetic acid-insoluble fraction was dissolved in $1 \mathrm{~mol} /$ liter $\mathrm{NaOH}$. $\left[{ }^{3} \mathrm{H}\right]$ thymidine incorporation into DNA was measured in three to four aliquots of this fraction using a liquid scintillation counter. The time-course of cell proliferation was evaluated for bone cells obtained from individual patients by measuring the peak of DNA synthesis (maximal uptake of tritiated thymidine during the time-course study), the time of peak occurrence, and the area under the growth curve, measured with a digitizing table coupled to an image analyzer (Leitz ASM). The overall proliferation of bone cell population was further estimated by determining the cumulative $\left[{ }^{3} \mathrm{H}\right]$ thymidine uptake into DNA up to day 14 of culture (cumulative peak) $(15,16)$. The cumulative peak and the area under the cumulative curve of DNA synthesis were determined from the time-course study obtained for each individual bone cell population.

Control values were obtained from cultures of osteoblastic cells isolated from normal trabecular bone obtained during surgery for arthropathic disease in 11 age-matched normal individuals (mean age \pm SD: $60.4 \pm 14.7 \mathrm{yr}$; range: $45-83 \mathrm{yr}$ ). Control values for growth cell kinetics could be obtained from six of these normal individuals (mean age: $66.7 \pm 15.8$; range: $50-83 \mathrm{yr}$ ). The mean age of controls and osteoporotic patients was not statistically different. The normal bone cell cultures were obtained using the procedure described above and were tested under the same conditions as for the cells from osteoporotic patients.

Statistical analysis. Differences between controls and $1,25(\mathrm{OH})_{2} \mathrm{D}-$ treated cell cultures were analyzed by unpaired Student's $t$ test. The mean values in the different groups of patients were compared using analysis of variance (minimum level of significance, $P<0.05$ ). The relations between histomorphometric measurements and bone cell culture data were analyzed by linear correlations (Spearman's test).

\section{Results}

Bone histomorphometric data. The histomorphometric analysis showed that bone formation parameters were variable in the 
whole group. The patients were thus separated into two groups according to DLS which represents the extent of actively bone forming surfaces. 14 osteoporotic men had DLS values lower than the mean value-2 SD in age-matched normal men (normal value $5.4 \pm 1.1[\mathrm{SD}]$ ) and were defined as having low bone formation. The other nine patients were considered to have a normal extent of bone forming surfaces as they had DLS values within the normal range (Fig. 1).

Table I shows that the mean trabecular bone volume in patients with low or normal DLS was lower than the values in normal age-matched men. Patients with low DLS had a lower than normal MWT, reduced osteoblast surface, decreased total labeled surface, and low BFR. The osteoblast surface, total labeled surface, double labeled surface, and BFR were lower in patients with decreased DLS than in the normal DLS group (Table I, Fig. 1). However, the mineral apposition rate was normal in the two groups of patients. DLS was found to correlate strongly with the osteoblast surface $(r=0.80, P<0.001)$.

Parameters of bone resorption were not different from normal in patients with low DLS. By contrast, the number of osteoclasts $/ \mathrm{mm}^{2}$ of bone tissue was higher than normal in patients with normal DLS (Table I).

Clinical and biochemical data. The incidence of vertebral fractures in patients with low DLS was identical to that in the patients with normal DLS (1.9 \pm 1.7 , range: $0-5[n=14]$ vs. $1.2 \pm 1.4$, range: $0-4[n=9]$ ). Almost all drinker/smoker patients $(12 / 13)$ had one or more vertebral fractures and the incidence of fractures was higher in these patients $(2.2 \pm 1.4)$ than in abstainers $(0.8 \pm 1.3)$ in whom only $4 / 10$ patients had one or more fractures. The mean serum osteocalcin concentrations were comparable in patients with low and normal DLS (6.5 \pm 2.6 , range: $2.9-9.4$ vs. $7.5 \pm 4.1$, range: $2-12 \mu \mathrm{g} /$ liter [SD]) and were not different from normal values for men (3.5-9.5 $\mu \mathrm{g} /$ liter). The mean serum osteocalcin was however slightly lower in drinkers/smokers than in abstainers (5.9 \pm 2.2 , range: $2.5-7.5$ vs. $8.3 \pm 3.8$, range: $2-12 \mu \mathrm{g} /$ liter).

Bone cell characteristics. Alkaline phosphatase activity in untreated bone cells was not different from normal in the two groups (Table II). 1,25(OH) $)_{2} \mathrm{D}(10 \mathrm{nmol} / \mathrm{liter}, 48 \mathrm{~h}$ ) had variable effects on alkaline phosphatase activity and the change was of similar amplitude in bone cells from osteoporotic men with low or normal DLS and in normal subjects.

Basal osteocalcin production by osteoblastic cells was not significantly different from normal in the two groups of patients. The response to $1,25(\mathrm{OH})_{2} \mathrm{D}$ was also similar as osteocalcin synthesis was increased to comparable levels in bone

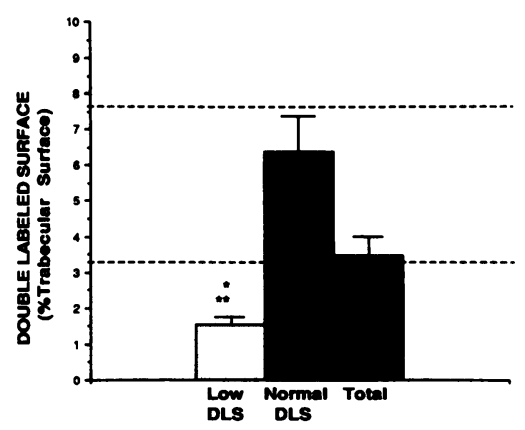

Figure 1. Mean $( \pm \mathrm{SE})$ DLS activity in men with idiopathic osteoporotics with low or high bone formation evaluated by DLS. The mean \pm 2 SD in agematched controls is indicated by the dotted lines. A significant difference with normal values and with the value in patients with normal DLS is indicated by one asterisk $(P<0.05)$ and two asterisks $(P<0.01)$, respectively. cells from osteoporotic patients and in normal subjects. Basal and osteocalcin production corrected for cell protein were also not significantly different in the two groups and the magnitude of response to $1,25(\mathrm{OH})_{2} \mathrm{D}$ was similar in patients with low and normal DLS and in normal subjects (Table II).

DNA synthesis. The proliferative characteristics of osteoblastic cells evaluated by $\left[{ }^{3} \mathrm{H}\right]$ thymidine incorporation into DNA indicate that bone cells from osteoporotic men with low DLS had a reduced rate of cell proliferation compared to normal bone cells. The time-course analysis of $\left[{ }^{3} \mathrm{H}\right]$ thymidine incorporation showed that DNA synthesis was lower than normal at day 9-14 of culture in bone cells from osteoporotic men with low DLS (Fig. 2). In these subjects, the mean peak of DNA synthesis (maximal $\left[{ }^{3} \mathrm{H}\right]$-thymidine uptake during the timecourse study) was $54 \%$ lower than normal (Table III). The mean cumulative peak of $\left[{ }^{3} \mathrm{H}\right]$ thymidine uptake at day 14 of culture was $23.5 \%$ lower than normal and the average area under the curve of cell proliferation was $30 \%$ lower than in normal bone cells (Table III). By contrast, the time-course study showed that DNA synthesis was identical to normal values in bone cells from osteoporotic patients with normal DLS (Fig. 2). The osteoblastic cells from these patients had a normal rate of cell proliferation in vitro as also shown by the normal proliferative characteristics of these cells (Table III).

In vitro parameters of cell proliferation were found to correlate with histomorphometric indices of bone formation. The area under the proliferative curve correlated linearly with the total labeled surface and with DLS (Fig. 3). Also, the osteoblastic surface $(r=0.39 ; P<0.05)$, DLS $(r=0.46 ; P<0.05)$, and the cumulative peak of DNA synthesis $(r=0.34 ; P<0.05)$ were found to decrease with the age of the patients.

\section{Discussion}

With the aim of establishing the cellular dysfunction responsible for the trabecular bone loss in men with eugonadal osteoporosis we have compared the histomorphometric indices of bone formation and the in vitro characteristics of osteoblastic cells isolated from the same trabecular bone. The activity of bone formation was evaluated by DLS as this dynamic parameter estimates the extent of actively bone forming surfaces $(15,18)$. DLS correlated with the extent of morphologically active osteoblasts which further indicates that this index represents the active osteoblastic population. As previously reported (18) a histologic heterogeneity was apparent in osteoporotic men. Some patients were found to have normal parameters of bone formation with increased bone resorption compared to age-matched nonosteoporotic men. Histomorphometric results in these patients showed a trend for a high osteoclast surface and significantly increased osteoclast number, suggesting that the reduced trabecular bone volume resulted from a higher rate of bone resorption relative to bone formation. In other patients including the two patients with involutional osteoporosis, the indices of bone formation were lower than normal with normal bone resorption parameters, suggesting that osteopenia resulted from defective bone formation. We found no difference in circulating osteocalcin levels in osteoporotic men with low and normal DLS, probably because of the limited number of patients in our study.

Patients with decreased DLS also had low osteoblast surface, reduced BFR, and lower than normal MWT. The mineral 
Table I. Histomorphometric Characteristics of Iliac Crest Trabecular Bone from Osteoporotic Men Subdivided According To the Extent of $D L S$

\begin{tabular}{|c|c|c|c|c|}
\hline & \multicolumn{3}{|c|}{ Osteoporotic men with } & \multirow{2}{*}{$\begin{array}{l}\text { Age-matched } \\
\text { controls }\end{array}$} \\
\hline & Decreased DLS & Normal DLS & Total & \\
\hline & $n=14$ & $n=9$ & $n=23$ & $n=8$ \\
\hline Age $y r$ & $57.5 \pm 10.2$ & $48.2 \pm 16.3$ & $53.9 \pm 13.4$ & $43.7 \pm 16.9$ \\
\hline (range) & $(39-75)$ & $(21-77)$ & $(21-77)$ & $(20-70)$ \\
\hline Trabecular bone volume (\% bone tissue) & $15.7 \pm 3.9^{*}$ & $16.2 \pm 3.7^{*}$ & $15.9 \pm 3.8^{*}$ & $20.3 \pm 3.1$ \\
\hline Mean wall thickness $(\mu m)$ & $44.0 \pm 8.6^{*}$ & $52.1 \pm 5.9$ & $46.8 \pm 8.6^{*}$ & $59.4 \pm 3.6$ \\
\hline Osteoblast surface (\% trabecular surface) & $1.88 \pm 1.20^{*}$ & $4.57 \pm 1.97^{\ddagger}$ & $2.93 \pm 2.02$ & $3.95 \pm 1.13$ \\
\hline \multicolumn{5}{|l|}{ Total labeled surface $(\%$ trabecular } \\
\hline surface) & $5.20 \pm 2.77^{*}$ & $11.76 \pm 4.62^{\ddagger}$ & $7.88 \pm 4.84$ & $11.81 \pm 1.03$ \\
\hline Mineral apposition rate $(\mu m / d)$ & $0.67 \pm 0.18$ & $0.67 \pm 0.12$ & $0.67 \pm 0.16$ & $0.66 \pm 0.10$ \\
\hline BFR $\left(\mu \mathrm{m}^{3} / \mu \mathrm{m}^{2}\right.$, day $)$ & $0.032 \pm 0.016^{*}$ & $0.079 \pm 0.027^{\ddagger}$ & $0.051 \pm 0.032$ & $0.077 \pm 0.012$ \\
\hline Osteoclastic surface (\% trabecular surface) & $0.57 \pm 0.44$ & $0.80 \pm 0.36$ & $0.66 \pm 0.42$ & $0.49 \pm 0.19$ \\
\hline Number of osteoclasts (per $\mathrm{mm}^{2}$ section) & $0.38 \pm 0.31$ & $0.53 \pm 0.28^{*}$ & $0.44 \pm 0.30$ & $0.16 \pm 0.09$ \\
\hline
\end{tabular}

Values are the mean \pm SD. ${ }^{*}$ Significant difference compared to age-matched controls $(P<0.05) .{ }^{\ddagger}$ Significant difference $(P<0.05)$ compared to the mean value in patients with decreased DLS.

apposition rate was, however, normal, indicating that the decreased trabecular bone volume in these patients resulted from a reduced osteoblastic population rather than alteration of the activity of individual osteoblasts. A defective bone formation due to decreased osteoblastic number or activity has been found in osteoporotic men who were mostly alcoholic and heavy smokers (8) and in nonalcoholic men with osteoporosis (14). Our report indicates that the decreased bone formation in men with idiopathic osteoporosis resulted from a lower than normal osteoblastic population rather than altered osteoblastic activity.

To establish whether the decreased bone formation in osteoporotic men with low DLS resulted from defective osteoblastic recruitment or function we have studied the parameters of bone cell proliferation and differentiation in vitro. Alkaline phosphatase activity and osteocalcin synthesis are parameters which characterize the osteoblastic phenotype (24). No significant difference was found in the basal osteocalcin production and alkaline phosphatase activity between the two groups of osteoporotic patients. The osteocalcin production in vitro in response to $1,25(\mathrm{OH})_{2} \mathrm{D}$ at optimal dosage and time of culture for human bone cells derived from the trabecular surface (21) was also not different in patients with low or normal DLS. In addition, basal values for osteocalcin and the amplitude of response to $1,25(\mathrm{OH})_{2} \mathrm{D}$ in osteoblastic cells from osteoporotic men were not different from the values in cells isolated from

Table II. Characteristics of Osteoblastic Cells Isolated from Men with Eugonadal Osteoporosis

\begin{tabular}{|c|c|c|c|c|}
\hline & \multicolumn{3}{|c|}{ Patients with } & \multirow[b]{2}{*}{$\begin{array}{l}\text { Normal bone } \\
\text { cells (10) }\end{array}$} \\
\hline & $\begin{array}{c}\text { Decreased DLS } \\
\text { (10) }\end{array}$ & $\begin{array}{c}\text { Normal DLS } \\
\text { (7) }\end{array}$ & $\begin{array}{l}\text { Total } \\
\text { (17) }\end{array}$ & \\
\hline \multicolumn{5}{|c|}{$\begin{array}{l}\text { Alkaline phosphatase activity (nmol } p \text {-nitrophenol } \\
\text { /min per mg protein) }\end{array}$} \\
\hline Untreated & $67.3 \pm 16.7$ & $35.4 \pm 11.1$ & $54.2 \pm 11.2$ & $42.5 \pm 15.2$ \\
\hline$+1,25(\mathrm{OH})_{2} \mathrm{D}$ & $88.8 \pm 23.2$ & $43.8 \pm 11.1$ & $70.4 \pm 15.1$ & $56.4 \pm 16.9$ \\
\hline \multicolumn{5}{|c|}{ Osteocalcin ( $\mu \mathrm{g} /$ liter) } \\
\hline Untreated & $0.60 \pm 0.09$ & $0.80 \pm 0.21$ & $0.68 \pm 0.10$ & $0.56 \pm 0.08$ \\
\hline $1,25(\mathrm{OH})_{2} \mathrm{D}$ & $1.19 \pm 0.27^{*}$ & $2.58 \pm 0.91^{*}$ & $1.75 \pm 0.39^{*}$ & $1.29 \pm 0.26^{*}$ \\
\hline$\%$ of change & $221 \pm 26$ & $593 \pm 254$ & $360 \pm 102$ & $237 \pm 42$ \\
\hline \multicolumn{5}{|c|}{ Osteocalcin (ng/mg protein) } \\
\hline Untreated & $8.09 \pm 2.11$ & $10.60 \pm 3.96$ & $8.81 \pm 1.83$ & $5.18 \pm 1.17$ \\
\hline $1,25(\mathrm{OH})_{2} \mathrm{D}$ & $16.45 \pm 2.38^{*}$ & $36.26 \pm 11.50^{*}$ & $22.11 \pm 4.20^{*}$ & $13.06 \pm 2.82^{*}$ \\
\hline$\%$ of change & $262 \pm 31$ & $655 \pm 375$ & $374 \pm 110$ & $257 \pm 50$ \\
\hline
\end{tabular}

Data are the mean \pm SE of values obtained from the number of patients in parentheses. The value for each patient is the average result of three to four separate cultures. ${ }^{*} P<0.05$ compared to untreated cells. 


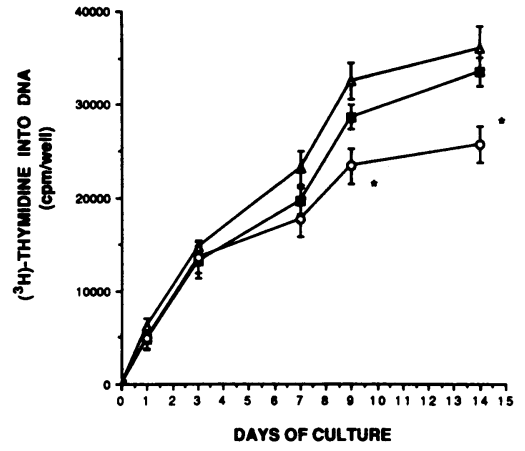

for each subject is the average of three to four separate cell cultures. *Significant difference from the value in normal bone cells $(P<0.05)$.

normal individuals. Thus, parameters of bone cell differentiation in vitro were not different from normal in osteoporotic men with low DLS, indicating that the decreased bone formation in these patients did not result from defective osteoblastic differentiation.

The evaluation of DNA synthesis evaluated by $\left[{ }^{3} \mathrm{H}\right]-$ thymidine uptake indicated that osteoblastic cells isolated from osteoporotic men with low DLS had a reduced capacity of proliferation at 9 and 14 days of culture, compared to normal bone cells cultured at identical cell density. The time-course study showed that this significant difference in DNA synthesis appeared relatively late in culture presumably because a fraction of the osteoblastic cells recovered in vitro from the in vivo influence of detrimental etiologic factors. By contrast we found that DNA synthesis by osteoblastic cells was normal in osteoporotic patients with normal bone formation. When the two groups of patients were pooled the defective bone cell proliferation was no longer apparent as we previously reported (25). The lower than normal DNA synthesis by bone cells found in patients with low bone formation was not due to a different proportion of differentiated osteoblasts in the cultures since osteocalcin production in basal conditions and in response to $1,25(\mathrm{OH})_{2} \mathrm{D}$ were identical to normal values. The finding that parameters of bone cell proliferation correlated with the histomorphometric indices of osteoblastic bone formation indicates that the decreased potential to proliferate of osteoblastic cells was responsible for the reduced MWT, and trabecular bone
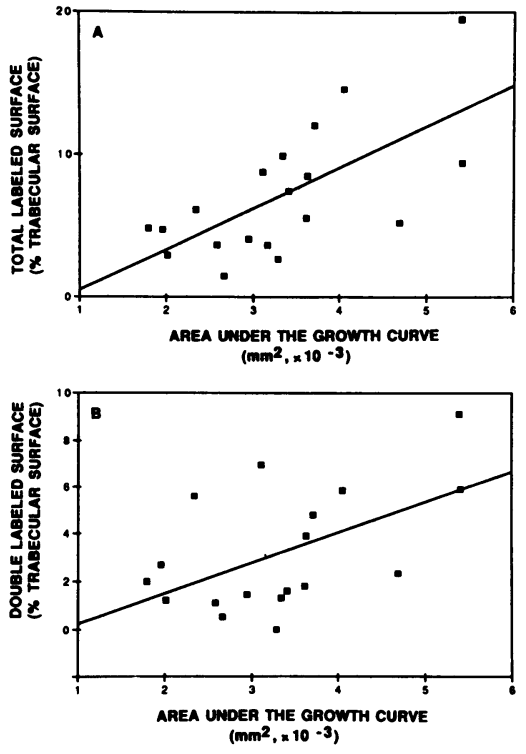

Figure 3. Correlations between in vitro osteoblastic cell proliferation evaluated by the area under the growth curve and the extent of trabecular bone forming sites evaluated as $(A)$ the total tetracycline labeled surface $(r=0.66$; $P<0.005)$ and $(B)$ the double labeled surface $(r=0.54 ; P<0.05)$ measured on bone biopsy in 20 osteoporotic men.

loss in these osteoporotic men. A similar mechanism involving an impaired proliferative capacity of osteoblastic precursors associated with reduced bone formation was previously reported by us in postmenopausal osteoporotic women (15). Because of the difficulties in obtaining trabecular bone specimens from osteoporotic men and age-matched normal individuals, the number of patients in this study was limited. Despite this limitation we found evidence of an association between diminished cell proliferation and decreased bone formation in a subgroup of osteoporotic men which is consistent with a decreased recruitment of osteoblasts in these patients. These findings have important therapeutic implications since they indicate that treatments aimed at correcting the defective recruitment of osteoblasts may be recommended in osteoporotic men with decreased bone formation.

Numerous mechanisms can be suggested for the pathogenesis of the osteoblastic dysfunction in eugonadal osteoporotic men. More than half of our osteoporotic men were alcohol drinkers. Most of these subjects (73\%) had low bone formation, reduced trabecular bone volume, and diminished bone cell proliferation in vitro, indicating that ethanol may be responsible for the impaired osteoblastic recruitment in these patients. Al-

Table III. Proliferative Characteristics of Osteoblastic Cells Isolated from Osteoporotic Men Compared to Normal Bone Cells as Evaluated by DNA Synthesis In Vitro

\begin{tabular}{|c|c|c|c|c|}
\hline & \multicolumn{3}{|c|}{ Patients with } & \multirow[b]{2}{*}{$\begin{array}{c}\text { Normal bone } \\
\text { cells (6) }\end{array}$} \\
\hline & $\begin{array}{c}\text { Decreased DLS } \\
\text { (13) }\end{array}$ & $\begin{array}{c}\text { Normal DLS } \\
\text { (7) }\end{array}$ & $\begin{array}{l}\text { Total } \\
\text { (20) }\end{array}$ & \\
\hline Peak of DNA synthesis (cpm/well) & $5476 \pm 878^{*}$ & $9408 \pm 1378$ & $7028 \pm 829$ & $11878 \pm 773$ \\
\hline Cumulative peak of DNA synthesis (cpm/well) & $25669 \pm 1947^{*}$ & $36015 \pm 2385$ & $29290 \pm 1862$ & $33533 \pm 1586$ \\
\hline Area under the curve $\left(\mathrm{mm}^{2}\right)$ & $961 \pm 78^{*}$ & $1322 \pm 143$ & $1088 \pm 79$ & $1307 \pm 71$ \\
\hline Area under the cumulative curve $\left(\mathrm{mm}^{2}\right)$ & $1336 \pm 87^{*}$ & $1768 \pm 102$ & $1487 \pm 95$ & $1575 \pm 61$ \\
\hline
\end{tabular}

The peak of DNA synthesis was the maximal uptake of tritiated thymidine during the time-course study. The cumulative peak of DNA synthesis represented the cumulative uptake of tritiated thymidine up to day 14 of culture. The area under the growth curve and the area under the cumulative growth curve were determined for each individual bone cell population during the time-course study of DNA synthesis. Data are the mean $\pm \mathrm{SE}$ of values obtained from the number of subjects in parentheses. The value in each patient is the average result of three to four separate cultures. ${ }^{*} P<0.05$ compared to the mean value in normal bone cells. 
cohol may however affect other cell types since ethanol has been reported to increase bone resorption in vitro (10) and in vivo (26).

Tobacco consumption is a risk factor for osteoporosis $(5$, 27 ) and $52 \%$ of our patients were mild smokers. Smoking has a detrimental effect on trabecular bone density (28) and bone formation (8). Although tobacco or alcohol use may be involved in the osteoblast dysfunction in osteoporotic men, these factors may not be of major importance in all patients since $27 \%$ of the drinkers/smokers had normal bone formation. Other contributing factors such as low body weight $(27,29)$, decreased physical activity (30), and genetic components (18) may also be important. Aging could also be one factor involved in osteoblast dysfunction as the two patients with involutional osteoporosis had decreased bone formation and subnormal bone cell growth in vitro. We also observed an inverse relationship between the extent of bone forming sites and DNA synthesis and age in our patients. Although parameters of bone formation have been reported to decrease with age in normal subjects (31) this point remains controversial. Further studies are required to establish whether there is a decrease in osteoblastic cell proliferation with age.

In conclusion, we found that the trabecular bone loss and decreased bone formation in most eugonadal men with idiopathic osteoporosis was associated with a lower than normal osteoblastic cell proliferation in vitro whereas parameters of bone cell differentiation were not affected. This study indicates that the defective bone formation and reduced osteoblast population in a subgroup of osteoporotic men results from an impaired proliferative capacity of osteoblastic cells lining the trabecular bone surface.

\section{Acknowledgments}

We want to thank Ms. C. Morieux for her technical assistance and Ms. B. Gouin for typing the manuscript.

\section{References}

1. Riggs, B. L., H. W. Wahner, W. L. Dunn, R. B. Mazess, K. P. Offord, and L. J. Melton III. 1981. Differential changes in bone mineral density of the appendicular and axial skeleton with aging. Relationship to spinal osteoporosis. J. Clin. Invest. 67:328-335.

2. Orwoll, E. S., and D. E. Meier. 1986. Alterations in calcium, vitamin D and parathyroid hormone physiology in normal men with aging: relationship to the development of senile osteopenia. J. Clin. Endocrinol. \& Metab. 63:1262-1269.

3. Parfitt, A. M., C. H. E. Mathews, A. R. Villanueva, M. Kleerekoper, B. Frame, and D. S. Rao. 1983. Relationships between surface, volume, and thickness of iliac trabecular bone in aging and in osteoporosis. Implications for the microanatomy and cellular mechanism of bone loss. J. Clin. Invest. 72:13961406.

4. Makins, N. B., J. E. Aaron, R. M. Francis, and M. Peacock. 1984. Trabecular bone loss from the iliac crest with age and osteoporosis. Microanatomical and histological changes. In Osteoporosis. Vol. 1. C. Christiansen, C. D. Arnaud, B. E. C. Nordin, A. M. Parfitt, W. A. Peck, and B. L. Rigg, editors. Aalborg Press, Stiftsbogtrykkeri, Denmark. 499-501.

5. Seeman, E., L. J. Melton III, W. M. O'Fallon, and B. L. Riggs. 1983. Risk factors for spinal osteoporosis in men. Am. J. Med. 75:977-983.

6. Saville, P. D. 1965. Changes in bone mass with age and alcoholism. J. Bone Jt. Surg. Am. Vol. 47:492-499.

7. Bikle, D. D., H. K. Genant, C. Cann, R. R. Recker, B. P. Halloran, and G. J. Strewler. 1985. Bone disease in alcohol abuse. Ann. Intern. Med. 103:42-48.
8. de Vernejoul, M. C., J. Bielakoff, M. Herve, J. Gueris, M. Hott, D. Modrowski, D. Kuntz, L. Miravet, and A. Ryckewaert. 1983. Evidence for defective osteoblastic function: a role for alcohol and tobacco consumption in osteoporosis in middle-aged men. Clin. Orthop. Relat. Res. 179:107-115.

9. Bell, N. H., R. T. Turner, and V. S. Greene. 1987. Demonstration that ethanol inhibits bone matrix synthesis and mineralization in the rat. In Calcium Regulation and Bone Metabolism. D. V. Cohn, T. J. Martin, and P. Meunier, editors. Excerpta Medica, Amsterdam. 636-640.

10. Farley, J. R., R. Fitzsimmons, A. K. Taylor, U. M. Jorch, and K. H. W. Lau. 1985. Direct effects of ethanol on bone resorption and formation in vitro. Arch. Biochem. Biophys. 238:305-314.

11. Diamond, T., D. Stiel, M. Lunzer, M. Wilkinson, and S. Posen. 1989. Ethanol reduces bone formation and may cause osteoporosis. Am. J. Med. 86:282-288.

12. Williams, A. R., N. G. Weiss, C. L. Ure, J. Ballard, and J. R. Daling. 1982 Effect of weight, smoking and oestrogen use on the risk of hip and forearm fractures in postmenopausal women. Obstet. Gynecol. 60:695-699.

13. Sparrow, M. S., A. J. Garvey, B. Rosner, and J. E. Silbert. 1982. The influence of cigarette smoking and age on bone loss in men. Arch. Environ. Health. 37:246-249.

14. Jackson, J. A., M. Kleerekoper, A. M. Parfitt, D. S. Rao, A. R. Villanueva and B. Frame. 1987. Bone histomorphometry in hypogonadal and eugonadal men with spinal osteoporosis. J. Clin. Endocr. \& Metab. 65:53-58.

15. Marie, P. J., A. Sabbagh, M. C. de Vernejoul, and A. Lomri. 1989. Osteocalcin and deoxyribonucleic acid synthesis in vitro and histomorphometric indices of bone formation in postmenopausal osteoporosis. J. Clin. Endocr. \& Metab. 69:272-279.

16. Marie, P. J., A. Lomri, M. C. de Vernejoul, C. Morieux, A. M. Graulet, J. Gueris, and F. Llach. 1989. Relationships between histomorphometric features of bone formation and bone cell characteristics in vitro in renal osteodystrophy. $J$. Clin. Endocr. \& Metab. 69:1166-1173.

17. Johnston, C. C., F. Melton, R. Lindsay, and D. M. Eddy. 1989. Clinical indications for bone mass measurements. J. Bone Miner. Res. 4(Suppl. 2):1-22.

18. Jackson, J. A., and M. Kleerekoper. 1990. Osteoporosis in men: diagnosis, pathophysiology, and prevention. Medicine (Baltimore). 69:137-152.

19. Kragstrup, J., F. Melsen, and L. Mosekilde. 1983. Thickness of bone formed at remodeling sites in normal human iliac trabecular bone: variations with age and sex. Metab. Bone Dis. \& Relat. Res. 5:17-22.

20. Parfitt, A. M., M. K. Drezner, F. H. Glorieux, J. A. Kanis, H. Malluche, P. J. Meunier, S. M. Ott, and R. R. Recker. 1987. Bone histomorphometry: standardization of nomenclature, symbols and units. J. Bone Miner. Res. 2:595599.

21. Marie, P. J., A. Lomri, A. Sabbagh, and M. Basle. 1989. Culture and behavior of osteoblastic cells isolated from normal trabecular bone surfaces. In Vitro Cell. \& Dev. Biol. 25:373-379.

22. Lomri, A., P. J. Marie, P. V. Tran, and M. Hott. 1988. Characterization of endosteal osteoblastic cells isolated from mouse caudal vertebrae. Bone (NY). 9:165-75.

23. Lowry, O. H., N. J. Rosebrough, A. L. Farr, and R. J. Randall. 1951. Protein measurement with the Folin phenol reagent. $J$. Biol. Chem. 193:265-275.

24. Rodan, G. A., and S. B. Rodan. 1983. Expression of the osteoblastic phenotype. In Annual Advances in Bone and Mineral Research. Vol. 2. W. A. Peck, editor. Elsevier/North Holland Publishing Co., Amsterdam. 244-285.

25. Marie, P. J., M. Hott, D. Connes, A. Lomri, M. C. de Vernejoul, A. M. Graulet, and J. Gueris. 1987. In vitro cell proliferation and response to hormones of osteoblastic cells isolated from male osteoporotic patients. Calcif. Tissue Int. 2:14a. (Abstr.)

26. Baran, D. T., S. L. Teitelbaum, M. A. Bergfeld, G. Parker, E. M. Cruvant, and L. V. Avioli. 1980. Effect of alcohol ingestion on bone and mineral metabolism in rats. Am. J. Physiol. 238:507-510.

27. Daniell, H. W. 1976. Osteoporosis of the slender smoker. Arch. Intern. Med. 136:298-304.

28. Pocock, N. A., J. A. Eisman, P. J. Kelly, P. N. Sambrook, and M. G. Yeates. 1989. Effects of tobacco use on axial and appendicular bone mineral density. Bone (NY). 10:329-331.

29. Crilly, R. G., and L. Delaquerrière-Richardson. 1990. Current bone mass and body weight changes in alcoholic males. Calcif. Tissue Int. 46:169-172.

30. Pocock, N. A., J. A. Eisman, M. G. Yeates, P. N. Sambrook, and S. Eberl. 1986. Physical fitness is a major determinant of femoral neck and lumbar spine bone mineral density. J. Clin. Invest. 78:618-621.

31. Garcia-Carasco, M., M. Gruson, M. C. de Vernejoul, M. A. Denne, and L. Miravet. 1988. Osteocalcin and bone morphometric parameters in adults without bone disease. Calcif. Tissue Int. 42:13-17. 